\title{
Kajian Potensi dan Pemanfaatan Energi Panas Bumi di Wilayah Kerja Panas Bumi Patuha Ciwidey
}

\author{
Mochammad Fa'iq Khasmadin', Udi Harmoko² \\ ${ }^{1}$ Magister Energi, Sekolah Pascasarjana, Universitas Diponegoro; \\ ${ }^{2}$ Departemen Fisika, Fakultas Sains dan Matematika, Universitas Diponegoro;
}

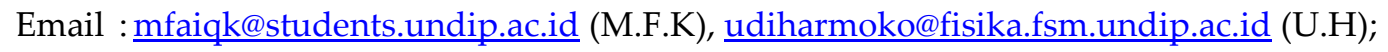

\begin{abstract}
Abstrak : Potensi energi panas bumi yang dimiliki oleh Indonesia sangat besar dan pemanfaatannya belum optimal. Data dari Badan Geologi Kementrian ESDM menunjukkan bahwa potensi energi panas bumi di Indonesia mencapai 29,5 GW atau 40\% dari potensi panas bumi di dunia. Pemanfaatan energi panas bumi di Indonesia untuk dikonversikan menjadi energi listrik sebesar 1.189 MW (tahun 2014). Keunggulan pemanfaatan energi panas bumi adalah energi bersih dan ramah lingkungan. Energi panas bumi mampu menggantikan pembangkit berbahan bakar batu bara ataupun gas. Upaya dalam pemanfaatan energi panas bumi adalah dengan melakukan pembangunan PLTP di area WKP yang memiliki potensi energi panas bumi yang besar salah satunya adalah WKP Patuha Ciwidey yang masih masuk dalam WKP Pangalengan. Saat ini Kapasitas pembangkit yang dibangkitkan adalah mencapai $1 \times 60 \mathrm{MW}$. Kajian dalam penelitian ini bertujuan untuk mengetahui potensi dan pemanfaatan energi panas bumi di WKP Patuha Ciwidey. Teknologi yang digunakan pada PLTP Patuha Unit 1 adalah siklus uap kering (Direct Dry Steam Cycle) Fluida uap dialirkan secara langsung ke Turbin. Sistem konversi ini merupakan sistem konversi yang paling sederhana. Dalam kajian ini ditemukan bahwa secara lateral terdapat tiga reservoir di area Patuha yang saling terhubung diantara Kawah Putih Cibuni, dan Ciwidey yang dipisahkan oleh Sesar Normal Cimanggu sehingg memisahkan antara area reservoir Kawah Cibuni dan reservoir Kawah Putih, sedangkan sesar normal Cileulur memisahkan area reservoir Kawah Putih dan area reservoir Kawah Ciwidey. Sedangkan Kebutuhan uap yang digunakan dalam pembangkitan PLTP unit 1 Patuha yakni dengan inlet pressure 11 bar abs, tekanan kondensor 0,1 bar abs, dari hasil perhitungan diperkirakan unit 1 Patuha membutuhkan uap sekitar 370,8 ton/jam atau $103 \mathrm{~kg} / \mathrm{s}$ dengan konsumsi uap rara-rata sebesar 6,75 ton/jamMW. Dalam upaya menjaga dan mengembangkan pemanfaatan energi diperlukan perencanaan desain proyek seumur hidup long life sustainability, dengan mempertimbangkan kondisi lingkungan, prediksi sumur, perencanaan steam field, dan simulasi reservoir.
\end{abstract}

Kata Kunci : Energi Panas Bumi, Reservoir Patuha, Siklus Uap Kering, Long Life Sustainability Project

Jurnal Energi Baru \& Terbarukan, 2021, Vol. 2, No. 2, pp $101-113$ 


\section{Pendahuluan}

Sebagai upaya pemerintah dalam memberikan ketahanan energi nasional yang diiringi dengan meningkatnya demand energi listrik di setiap tahunnya, Pemerintah Indonesia menyediakan sumber energi fosil dan energi baru terbarukan (EBT). Salah satu sumber energi yang sedang digalakkan oleh pemerintah Indonesia adalah sumber energi panas bumi. Hal ini dikarenakan Indonesia merupakan negara dengan jaringan gunung api karena terletak diantara tiga lempeng tektonik (Eropa-Asia, IndiaAustralia, dan Pasifik). Sehingga memiliki potensi energi panas bumi yang besar.

Sumber energi panas bumi merupakan sumber energi primer yang dapat diperbarui. Berdasarkan data dari Kementrian ESDM Indonesia memiliki Potensi panas bumi sebesar 29,5 GW, nilai potensi tersebut akan terus meningkat seiring dilakukannya kegiatan eksplorasi. Data sumber energi panas bumi di Indonesia yang dimanfaatkan hingga tahun 2020 adalah sebesar 3.109,5 MW (Rencana Umum Energi Nasional, 2020), artinya energi yang dimanfaatkan hanya sebesar 10,5\% dari potensi energi termanfaatkan. Upaya peningkatan pemanfaatan sumber energi baru terbarukan oleh Pemerintah Indonesia melalui Kementrian ESDM dilakukan dengan melakukan pembangunan Pembangkit Listrik Tenanga Panas bumi (PLTP) melalui perusahaan milik negara atau dengan pemberian ijin pengolaha Wilayah Kerja Panas Bumi (WKP) yang diberikan kepada perusahaan swasta (IPP).

Salah satu perusahaan milik pemerintah yang mendapatkan mandat dari pemerintah Indonesia untuk menjalankan bisnis pengolahan dan proyek panas bumi adalah PT Geo Dipa Energi (persero). Total kapasitas PLTP yang dioperasikan oleh PT Geo Dipa Energi (persero) saat ini adalah 120MW dengan dua PLTP yakni PLTP Dieng-1 (Jawa Tengah) dan PLTP Patuha-1. Dalam jurnal ini akan difokuskan untuk mengkaji potensi dan pemanfaatan energi panas bumi di unit wilayah kerja panas bumi Patuha.

\section{Pemanfaatan Energi Panas Bumi di Indonesia}

\subsection{Kajian Energi Panas Bumi di Indonesia}

Kondisi geologis negara Indonesia yang berada di area cingcin gunung api dunia menghasilkan banyaka potensi panas bumi yang terbentang dari Sumatera, Jawa, Bali, Nusa Tenggara, Sulawesi dan Maluku. Selain itu susur panas bumi yang merupakan bekas dari gunung api purba terdapat di Bangka Belitung, Papua Barat, Kalimantan, Riau, dan Yogyakarta. Jumlah potensi panas bumi yang terbukti di Indonesia dia tahun 2020 adalah 3.387 MW dengan total cadangan 14.626,5 MW.

Pada tahun 2015, kapasitas terpasang Pembangkit Listrik Tenaga Panas Bumi (PLTP) sebesar 1.438 MW dan mengalami peningkatan menjadi sebesar 2.131 MW pada tahun 2019. Tambahan kapasitas PLTP sebesar 140 MW di tahun 2018 berasal dari PLTP Karaha unit 1 (30 MW) dan PLTP Sarulla unit 3 (110 MW). Sedangkan tambahan kapasitas pada tahun 2019 sebesar 182,3 MW berasal dari PLTP Lumut Balai 55 MW, PLTP Sorik Marapi 42,3 MW dan PLTP Muaralaboh 85 MW (Tabel 1).

Kapasitas terpasang PLTP tersebut hanya sekitar $8 \%$ dari potensi panas bumi Indonesia sekitar 25,38 GW. Dalam rangka peningkatan kapasitas pembangkit ke depan, hingga saat ini telah ditetapkan 64 Wilayah Kerja Panas Bumi (WKP), yang terdiri dari 17 WKP Eksisting (sebelum Terbit UU Nomor 27 Tahun 2003 tentang Panas Bumi) dan 47 Wilayah Kerja Panas Bumi (setelah UU Nomor 27 Tahun 2003 Tentang Panas Bumi) yang dimuat pada Gambar 1. 
Tabel 1.

Data Potensi Panas Bumi Indonesia 2020 (RUEN, 2020)

\begin{tabular}{|c|c|c|c|c|c|c|c|c|}
\hline \multirow{3}{*}{ No. } & \multirow{3}{*}{ Pulau } & \multicolumn{7}{|c|}{ Sumber Daya (MW) } \\
\hline & & \multirow{2}{*}{ Lokasi } & \multirow{2}{*}{ Spekulatif } & \multirow{2}{*}{ Hipotetik } & \multicolumn{3}{|c|}{ Cadangan } & \multirow{2}{*}{$\begin{array}{l}\text { Kapasitas } \\
\text { Terpasang }\end{array}$} \\
\hline & & & & & Mungkin & Terduga & Terbukti & \\
\hline 1 & Sumatera & 101 & 2.276 & 1.557 & 3.735 & $1.040,7$ & $1.070,3$ & 744,3 \\
\hline 2 & Jawa & 73 & 1.265 & 1.190 & 3.414 & 418 & 1.820 & $1.253,8$ \\
\hline 3 & Bali & 6 & 70 & 21 & 104 & 110 & 30 & 0 \\
\hline 4 & Nusa Tenggara & 31 & 190 & 148 & 892 & 121 & 12,5 & 12,5 \\
\hline 5 & Kalimantan & 14 & 151 & 18 & 13 & 0 & 0 & 0 \\
\hline 6 & Sulawesi & 90 & 1.365 & 362 & 1.041 & 180 & 120 & 120 \\
\hline 7 & Maluku & 33 & 560 & 91 & 497 & 6 & 2 & 0 \\
\hline 8 & Papua & 3 & 75 & 0 & 0 & 0 & 0 & 0 \\
\hline \multirow{3}{*}{\multicolumn{2}{|c|}{ Total }} & \multirow{3}{*}{351} & \multirow{2}{*}{5.952} & \multirow{2}{*}{3.387} & 9.696 & $1.875,7$ & $3.054,8$ & \multirow{3}{*}{$2.130,6$} \\
\hline & & & & & & $14.626,5$ & & \\
\hline & & & & & $23.965,5$ & & & \\
\hline
\end{tabular}

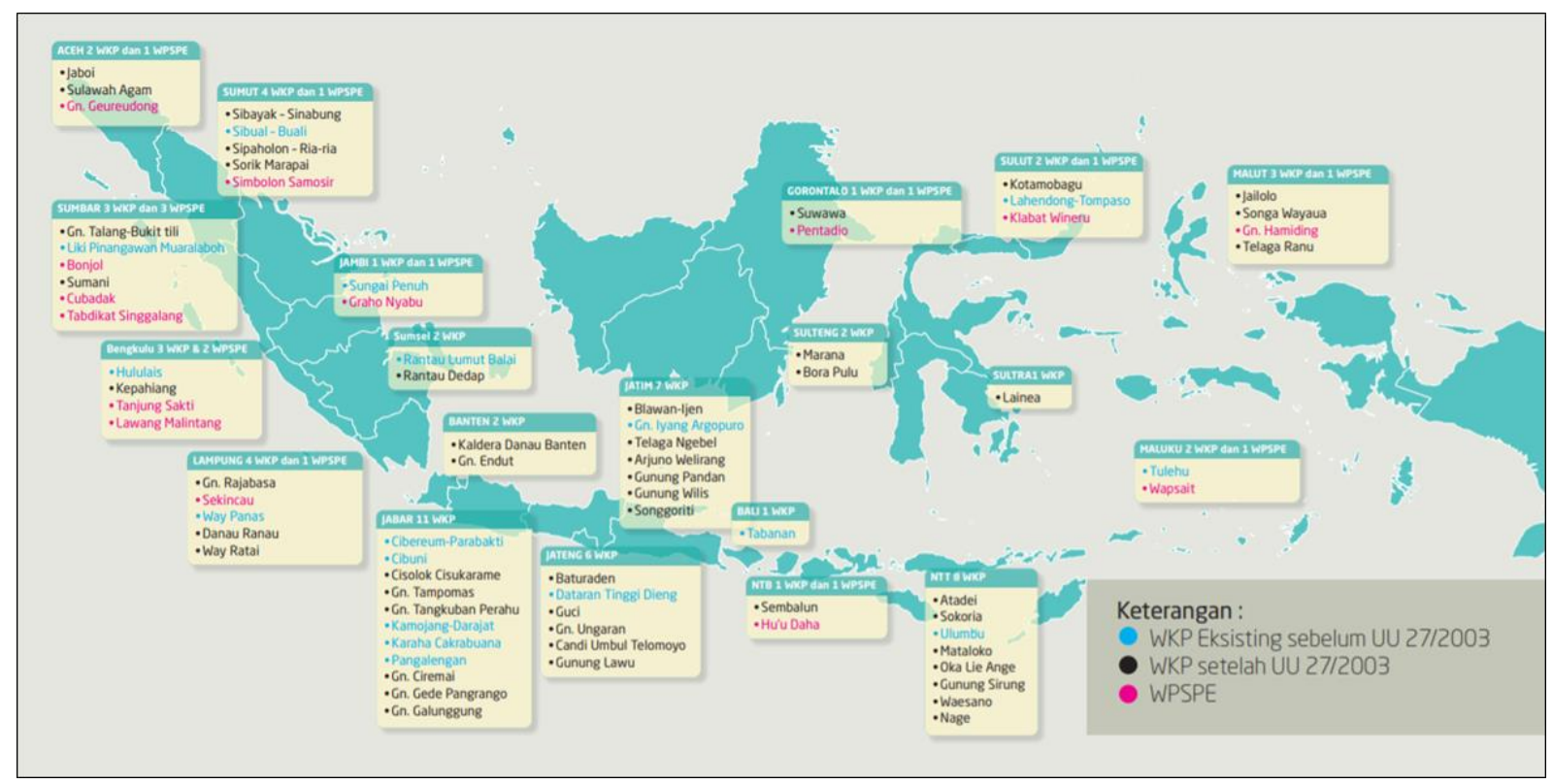

Gambar 1. Peta Wilayah Kerja Panas Bumi menurut WSPE dan UU 27/2003 (Sumber: RUEN 2020)

\subsection{Wilayah Kerja Panas Bumi Patuha}

Area wilayah kerja panas bumi Patuha diantaranya adalah Gunung Patuha, Kawah Ciwidey, dan Cibuni. Area ini tergabung dalam satu area WKP Pangalengan yakni Gunung Wayang Windu. Pemegang izin area Patuha adalah PT Geo Dipa Energi (Persero), sedangkan di Wayang Windu PT Pertamina Geothermal Energy KOB PT Star Energy Wayang Windu. Saat ini kapasitas PLTP terpasang di unit Patuha 1 yaitu $55 \mathrm{MW}$, sedangkan cadangan terduga adalah $17 \mathrm{MWe}$, cadangan mungkin 210 MWe, dan cadangan terbukti adalah 190 MWe. Hingga pada tahun 2021 total kapasitas terpasang unit pembangkit adalah $282 \mathrm{MW}$ dengan rincian (Wayang Windu 1 sebesar $110 \mathrm{MW}$, Wayang Windu 2 sebesar 117 MW, dan Patuha 1 sebesar 55 MW). 
Integrasi data-data subsurface seperti data geologi, geofisika, sebagian geokimia dan data pendukung lain seperti data pressure dan temperature survey menghasilkan konseptual model untuk lapangan panas bumi Patuha. Patuha geothermal sistem terdiri dari 1 reservoir dengan 1 upflow terletak di G. Patuha berupa acid core kawah putih yang asam dengan $\mathrm{pH}$ surface $<1$.

Up flow kawah putih mengalir baik ke arah barat dan ke arah timur. Ke arah barat, aliran kawah putih bergerak menuju kawah cibuni sampai Teknosa kontrak area. Hal ini didukung dengan elevasi temperatur yang semakin dalam semakin ke arah barat serta kemunculan beberapa manifestasi seperti kawah cibuni. Selain itu dari data 2D MT, penyebaran low resistive zone (caprock) semakin menebal dan mendalam ke arah barat, mengindikasikan berkurangnya intensitas vertical flow dan berubah menjadi lateral flow. Sementara itu, aliran kawah putih ke arah timur bergerak menuju kawah ciwidey.

Air meteorik dari area G. Puncaklawang dan sekitar Pasir Cacing meresap dari permukaan melalui pori - pori batuan yaitu satuan batuan Breksi Keneng Walam yang berada di bagian tenggara lapangan. Air meteorik terpanaskan karena adanya sumber panas yang berasosiasi dengan G. Patuha dan intrusi vulkanik G. Urug. Air tersebut kemudian tersimpan dan bersikulasi membentuk reservoir air (deep liquid zone) yang memiliki karakteristik dilute Na-Cl-SO4. Deep liquid atau parent liquid yang bersifat immobile dan terpanaskan kemudian mengalami proses boiling sehingga menghasilkan fluida reservoir (air dan uap). Parent fluid berasal dari area sekitar sumur PPL-2. Kemunculan fumarole dan mata air panas K. Ciwidey merupakan aliran vertical uap reservoir yang telah mengalami boiling. Kemunculannya ke permukaan dikontrol oleh sesar normal Ciwidey. Air panas Ciwidey yang bertipe asam sulfat terbentuk akibat kondensasi uap reservoir di dekat permukaan (steam heating).

Geo Morfologi Area Patuha Berdasarkan klasifikasi van Zuidam (1985) yang dilihat dari perbedaan morfografi dari hasil analisis citra satelit, pola kontur dari peta topografi dan hasil pengamatan lapangan, maka geomorfologi daerah Gunung Patuha dan sekitarnya dapat dibedakan menjadi:

1) Morfologi Perbukitan Gunung api Tua

2) Morfologi Kerucut dan Kawah Gunung Patuha Muda

3) Morfologi Kerucut dan Kawah Gunung Patuha Tua

4) Morfologi Perbukitan Sedang-Landai

5) Morfologi Dataran Aliran Lahar

Analisis geomorfologi dari satuan geomorfologi tersebut dilakukan dengan mengamati bentuk morfologi, kemiringan lereng, pola aliran sungai, jenis litologi, dan proses geomorfik yang terjadi.

Litologi/Stratigrafi Aktivitas vulkanisme di komplek G. Patuha dimulai pada Pliosen Awal yang ditandai dengan kemunculan beberapa pusat erupsi. G. Kendeng merupakan pusat volkanik termuda yang berlokasi $12 \mathrm{~km}$ arah baratlaut dari G. Patuha (Alhamid, 1989). Erupsi awal dicirikan oleh produk andesitik-basal, lava andesit, dan breksi andesit yang hadir di bagian timurlaut dan selatan komplek G. Patuha. Aktivitas di waktu berikutnya Plistosen muda-menengah terpusat di sekitar G. Patuha, yang didominasi oleh lava andesit dan material piroklastik.

Hasil Analisa Lainnya menunjukkan bahwa di lapangan Patuha terbagi menjadi 49 satuan batuan. Satuan tersebut dibagi berdasarkan sumber erupsinya, yaitu G. Kendeng tiga satuan, G. Aseupan satu satuan, G. Geulis satu satuan, G. Mas satu satuan, G. Tilu satu satuan, G. Wayang dua satuan, G. Kolalok dua satuan, G. Batu dua satuan, G. Tambakruyung tiga satuan, G. Tikukur satu satuan, G. Patuha sembilan satuan, G. Pawey satu sauan, G. Bengbreng satu satuan, G. Kantidua 
satuan, G. Panganten satu satuan, G. Beser satu satuan, G. Urug satu satuan, G. Parung satu satuan, G. Puncak Lawan tiga satuan, G. Dewata satu satuan, G. Waringin satu satuan, G. Karang Tengah satu satuan, G. Maud satu satuan, G. Sumbul satu satuan, G. Londok satu satuan, G. Sumbu satu satuan, G. Perak satu satuan, G. Bucecen satu satuan, G. Tugu satu satuan, G. Barangad satu satuan dan G. Kuda satu satuan. Batuan penyusun Lapangan Panas Bumi Gunung Patuha didominasi oleh endapan lava.

Berdasarkan Ringkasan Geokimia, Pada diagram segitiga $\mathrm{Cl}-\mathrm{SO}_{4}-\mathrm{HCO}_{3}$, hanya air panas Cimanggu 1 yang termasuk tipe air bikarbonat. Sedangkan Kawah Putih termasuk dalam Volcanic Water yang memiliki pH sangant rendah. Kawah Tiis, Kawah Ciwidey, Kawah CIbuni, dan Cisaat termasuk pada kelompok steam heated water yang menandakan adanya kondensasi uap di dekat permukaan. Pada diagram Na-K-Mg seluruh sample terletak pada immature water, yang menunjukan bahwa telah terjadi percampuran dengan fluida dangkal. Pada diagram segitiga Cl-Li-Boron, nilai boron pada sample sangat kecil. Sample air panas berada pada zona mengarah Cl-Li. Perhitungan geotermometer air panas, berdasarkan geothermometer Na-K-Ca menghasilkan temperatur yang cukup tinggi, yaitu $235^{\circ} \mathrm{C}$. Berdasarkan geotermometer $\mathrm{SiO}_{2}$ conductive cooling, mengacu kepada Fornier, 1981, melalui persamaan :

$$
\mathrm{T}\left({ }^{\circ} \mathrm{C}\right)=\frac{1.309}{5,19-\log \left(\mathrm{SiO}_{2}\right)}-273,15
$$

Didapatkan temperatur yang rendah sekitar $123^{\circ} \mathrm{C}$. Berdasarkan geotermometer $\mathrm{NaK}$, mengacu kepada Giggenbach, 1988, melalui persamaan :

$$
\mathrm{T}\left({ }^{\circ} \mathrm{C}\right)=\frac{1.309}{\log \left(\frac{\mathrm{Na}}{\mathrm{K}}\right)+1.750}-273,15
$$

Didapatkan temperatur terlalu tinggi. Temperatur hasil geothermometer $\mathrm{SiO}_{2}$ yang terlalu rendah, dan hasil geothermometer $\mathrm{NaK}$ yang terlalu tinggi $\left(248^{\circ} \mathrm{C}-462^{\circ} \mathrm{C}\right)$, menyebabkan kedua geothermometer ini tidak dapat merepresentasikan kondisi temperatur bawah permukaan di daerah Patuha.

Berdasarkan Ringkasan Geofisika menyebutkan bahwa Struktur resistivitas stiching 1-D di Daerah Patuha cukup memberikan resolusi yang tegas terkait ketebalan claycap dan keberadaan reservoir. Struktur resistivitas mengindikasikan keberadaan zona resistivitas rendah (konduktor) yang merepresentasikan keberadaan claycap dari dekat permukaan hingga sekitar elevasi $1.000 \mathrm{msl}$. Di bawah claycap ini terdapat indikasi reservoir yang elevasi batas atasnya bervariasi antara 1.250 hingga 1.000 msl. Hasil inversi 3-D mengkonfirmasi keberadaan claycap serta reservoir di bawah stasiunstasiun MT terkait. Akan tetapi di bagian barat lintasan pada hasil inversi 3D ini terdapat nilai resistivitas yang cukup rendah hingga kedalaman yang cukup dalam. Secara umum hasil inversi 3D memberikan gambaran struktur resistivitas secara realistis akan tetapi untuk mendapatkan struktur resistivitas yang lebih detail didapatkan melalui analisis 2-D. Sehingga kedua hasil tersebut dapat saling melengkapi dan memperkuat interpretasi. 


\subsection{Teknologi Pemanfaatan Potensi Energi Panas Bumi}

Sistem Konversi aliran fluida dari panas bumi mengubah energi dari steam menjadi energi listrik (Saptaji, 2020). Prinsip kerja dari Pembangkit Listrik Tenaga Panas Bumi (PLTP) pada dasarnya sama seperti Pembangkit Listrik Tenaga Uap (PLTU). Perbedaanya terletak dari sumber steam yang mana PLTU bersumber dari hasil pemanasan boiler dan PLTP berasal dari reservoir panas bumi. Fasa uap dari panas bumi dialirkan menuju turbin yang mana akan mengubah energi geothermal menjadi gerak kemudian dikopel dengan generator untuk diubah menjadi energi listrik, sedangkan steam dengan dua fasa (uap dan air) diperlukan proses pemisahan zat. Teknologi yang digunakan adalah separator sehingga fasa uap akan dipisahkan dengan fasa cair. Fraksi uap/steam yang dihasilkan dari separator kemudian dialirkan ke Turbin.

Teknologi yang digunakan pada PLTP Patuha Unit 1 adalah siklus uap kering (Direct Dry Steam Cycle) Fluida uap dialirkan secara langsung ke Turbin. Sistem konversi ini merupakan sistem konversi yang paling sederhana. Steam output dari turbin dialirkan ke kondenser untuk dikondensasikan. Kemudian kondensat dialirkan ke cooling tower dan selanjutnya diinjeksikan kembali ke bawah permukaan bumi yang diilustrasikan pada Gambar 2.

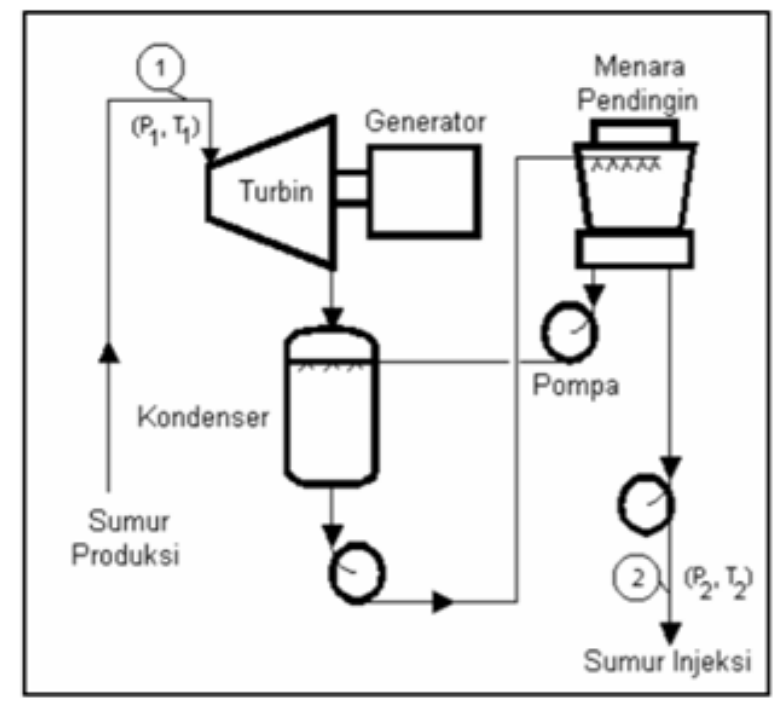

Gambar 2. Skema Pembangkitan Siklus Uap Kering (Saptaji, 2012)

\section{Kajian dan Diskusi}

\subsection{Kajian Sistem Geothermal di Steamfield Patuha}

Kajian geologis letak steamfield Patuha dekat dengan kawasan wisata kawah putih Ciwidey, tidak jauh dari lokasi lapangan Kamojang, Darajat dan Wayang Windu yang dimuat pada Gambar 3. Menurut Saptaji (2020) menunjukkan bahwa manifestasi permukaan yang ada di steamfield Patuha terdiri dari fumarol, mata air panas, dan keluaran gas dingin. Manifestasi fumarol terjadi pada Kawah Putih, Kawah Cibuni dan Kawah Ciwidey yang dimuat pada Gambar 3. Sehingga dengan indikasi tersebut terdapat aliran uap dari bawah permukaaan melalui rekahan atau zona permeabel.

Menurut Layman dan Soemarinda (2003), Gambar 5 memuat beberapa komponen utama, yaitu reservoir uap yang berada di atas zona air, magnetic plume, estimasi temperatur di bawah permukaan, zone upflow, serta perkiraan arah pergerakan fluida dibawah permukaan. Magnetic plume mengandung 
Vol. 2, No. 2, pp $101-113$

doi: $10.14710 /$ jebt.2021.11187

superheated steam dan membawa gas-gas asam ( $\mathrm{HCL}, \mathrm{HF}$, dan $\mathrm{SO}_{2}$ ). Interaksi uap tersebut dengan air permukaan dengan menghasilkan air Danau Kawah Putih. Danau Kawah Putih merupakan puncak Kawah Gunung Patuha yang memiliki karakteristik air asam dengan $\mathrm{PH}<0.5-1.3$.

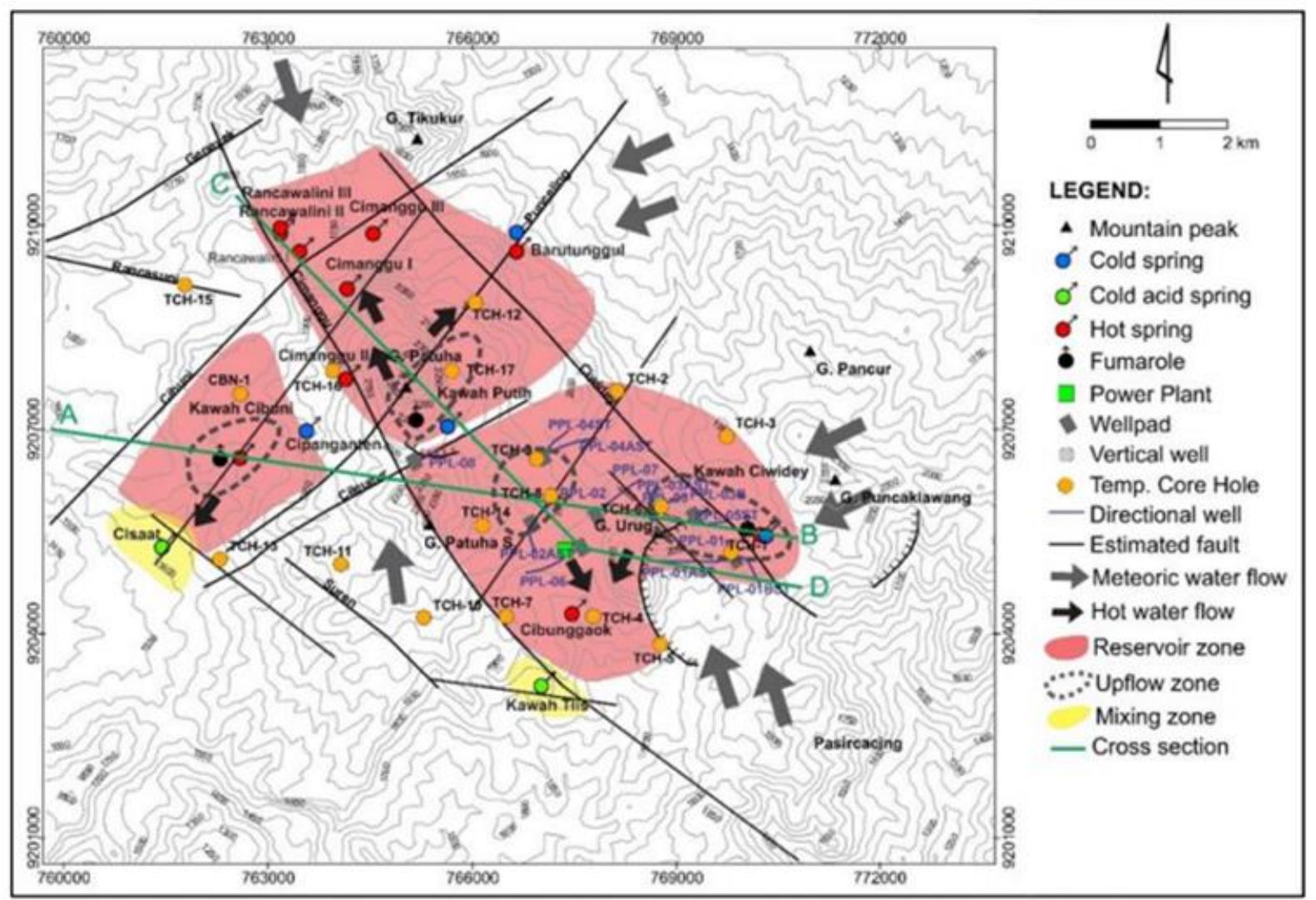

Gambar 3. Peta Lokasi Kawasan Geothermal Patuha (Ali Ashat, 2017)

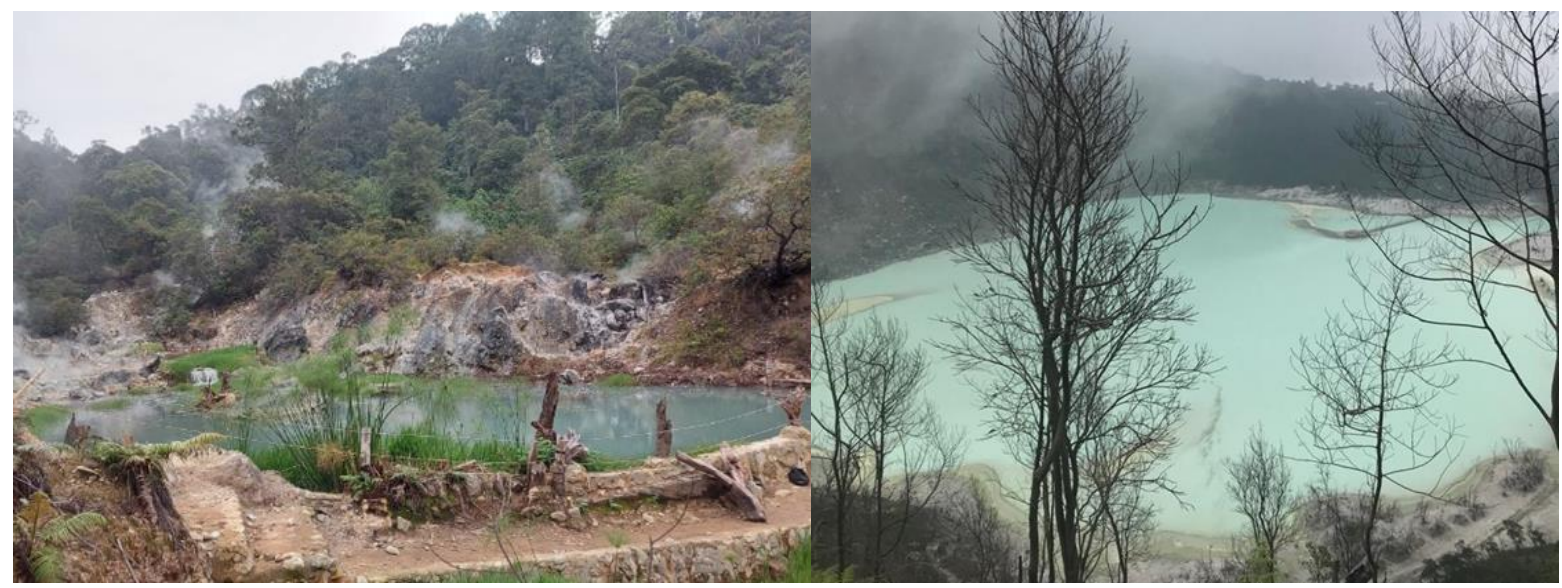

Gambar 4. Manifestasi di Kawasan Patuha (Dokumentasi Penulis) 


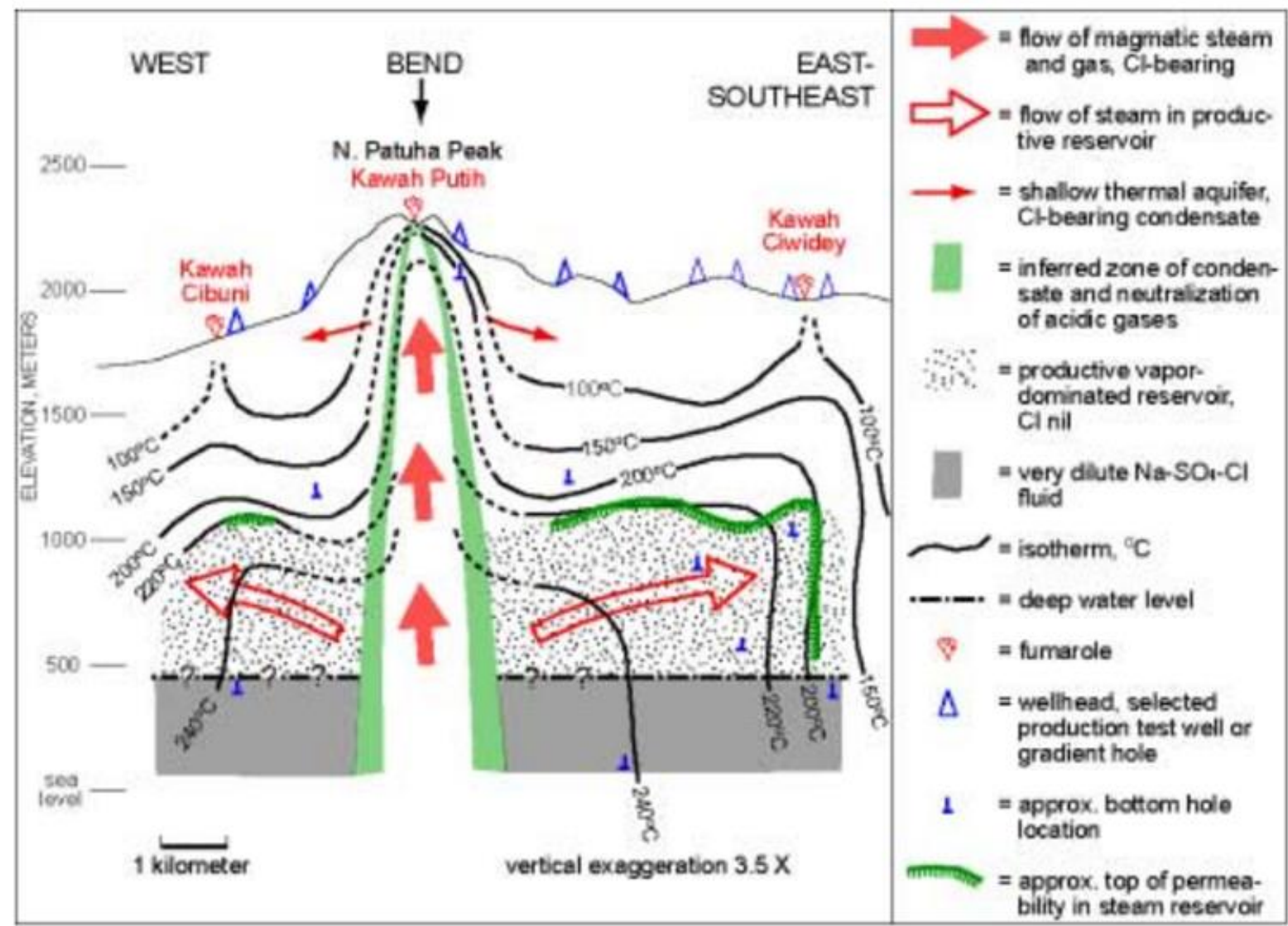

Gambar 5. Model Konsep Sistem Geothermal di Patuha (Layman dan Soemarinda, 2003)

Menurut Saptaji (2020), dari hasil kajian diambil simpulan bahwa reservoir geothermal di Patuha merupakan reservoir dua fasa dominasi uap yang dikontrol oleh struktur yang memiliki luas mencapai $20 \mathrm{~km}$. Hal ini terlihat dari landaian tekanan dan temperatur di sumur-sumur yang dibor di Lapangan Patuhan dengan kedalaman $1.019 \mathrm{~m}$ hingga $2.172 \mathrm{~m}$ menembus zona reservoir pada elevasi kurang dari 500mdpl. Landaian tekanan dan temperatur diperlihatkan pada Gambar 6, yang mengintepretasikan bahwa Sumur PPL-02 menunjukkan adanya zona dua fasa (Boiling Zone) di atas zona air, sedangkan sumur PPL-03 adalah sumur dangkal dan hanua menembus zona uap. Penelitian dari Ashat (2017), menunjukkan bahwa Tekanan dan temperatur di reservoir dangkal menunjukkan tekanan statis dan suhu konvektif ditunjukkan dengan uap jenuh dan reservoir permeabilitas tinggi (PPL-2AST, PPL-03AST, PPL-05ST, PPL-07). Sebaliknya, reservoir yang menunjukkan fasa cair (PPL01AST, PPL-06) Hal ini dikarenakan pada elevasi di bawah 500 mdpl yang memiliki profil tekanan hidrostatik yang menunjukkan cairan terkompresi.

Menurut Pratama (2016) Adanya kolom cairan juga telah dibuktikan dengan perubahan gradien tekanan model pada sekitar $500 \mathrm{mdpl}$ disertai dengan profil temperatur di bawah saturasi. Perubahan gradien tekanan disebabkan oleh perubahan densitas air di mana kondisi cair memiliki densitas yang lebih besar, begitu juga dengan tekanan hidrostatiknya. Semua sumur PPL menunjukkan profil temperatur konvektif yang menunjukkan area produksi memiliki permeabilitas yang baik. Berdasarkan karakteristik data sumur, lapangan panas bumi Ciwidey-Patuha didominasi uap dengan zona uap yang mendasari reservoir cair dalam. 
Vol. 2, No. 2, pp $101-113$

doi: 10.14710/jebt.2021.11187

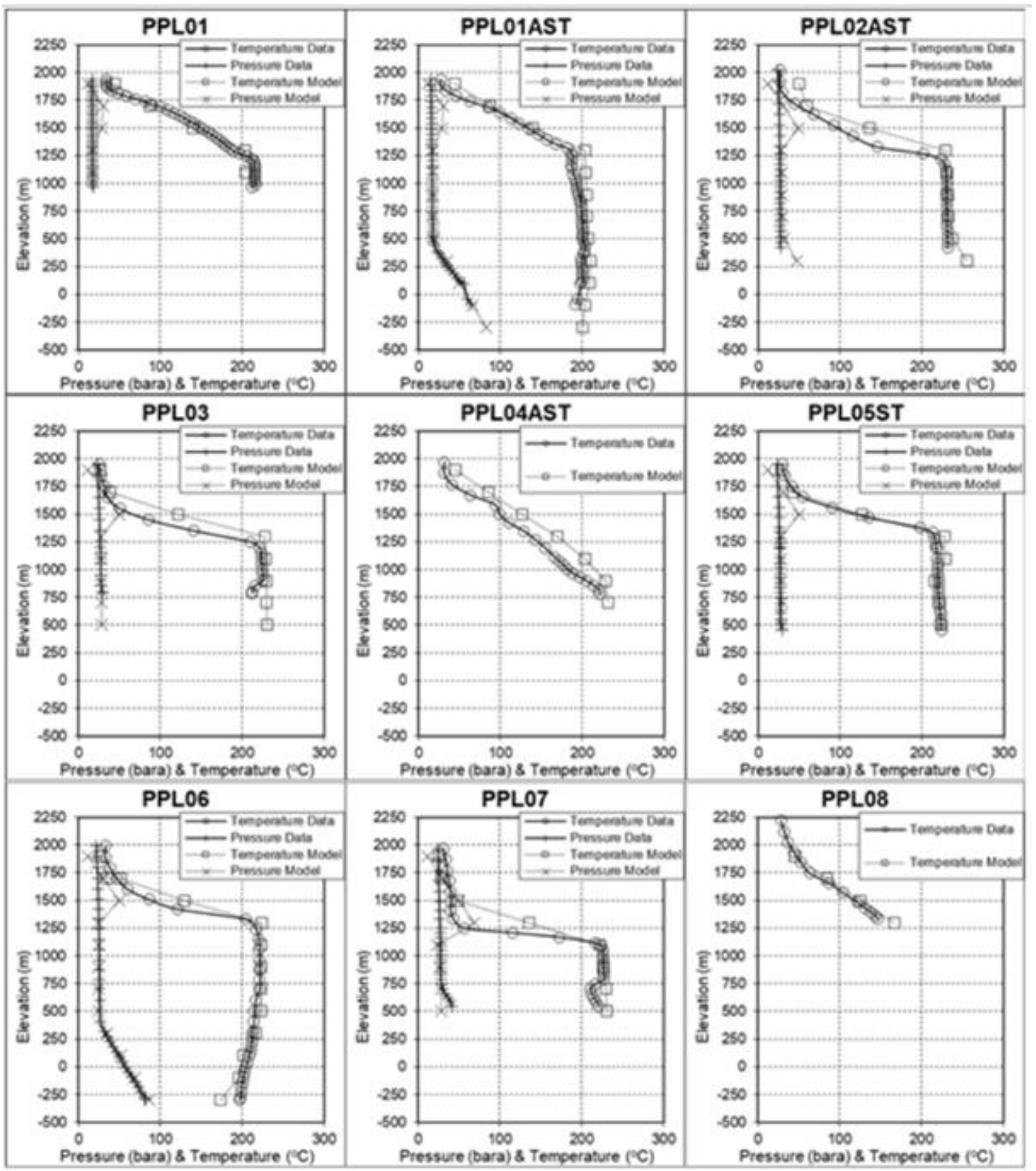

Gambar 6. Data Landaian Tekanan dan Temperatur dari Semua Sumur di Steamfield Patuha (Ashat, 2017)

Menurut Yosi Amelia (2014) Pola aliran fluida reservoir Patuha secara analisi kimia fluida dan isotop, analisis fluida thermal pada manifestasi dan sumur, analisia kimia air sumur dan kondensat, data geochemist manifestasi permukaan, serta data geochemist sumur yang dimiliki perusahaan. Dari kajian tersebut menunjukkan bahwa secara lateral terdapat tiga reservoir di area Patuha. Reservoir tersebut saling terhubung diantara Kawah Putihm Cibuni, dan Ciwidey. Sesar Normal Cimanggu memisahkan antara area reservoir Kawah Cibuni dan reservoit Kawah Putih, sedangkan sesar normal Cileulur memisahkan area reservoir Kawah Putih dan area reservoir Kawah Ciwidey. 
Vol. 2, No. 2, pp $101-113$

doi: $10.14710 /$ jebt.2021.11187

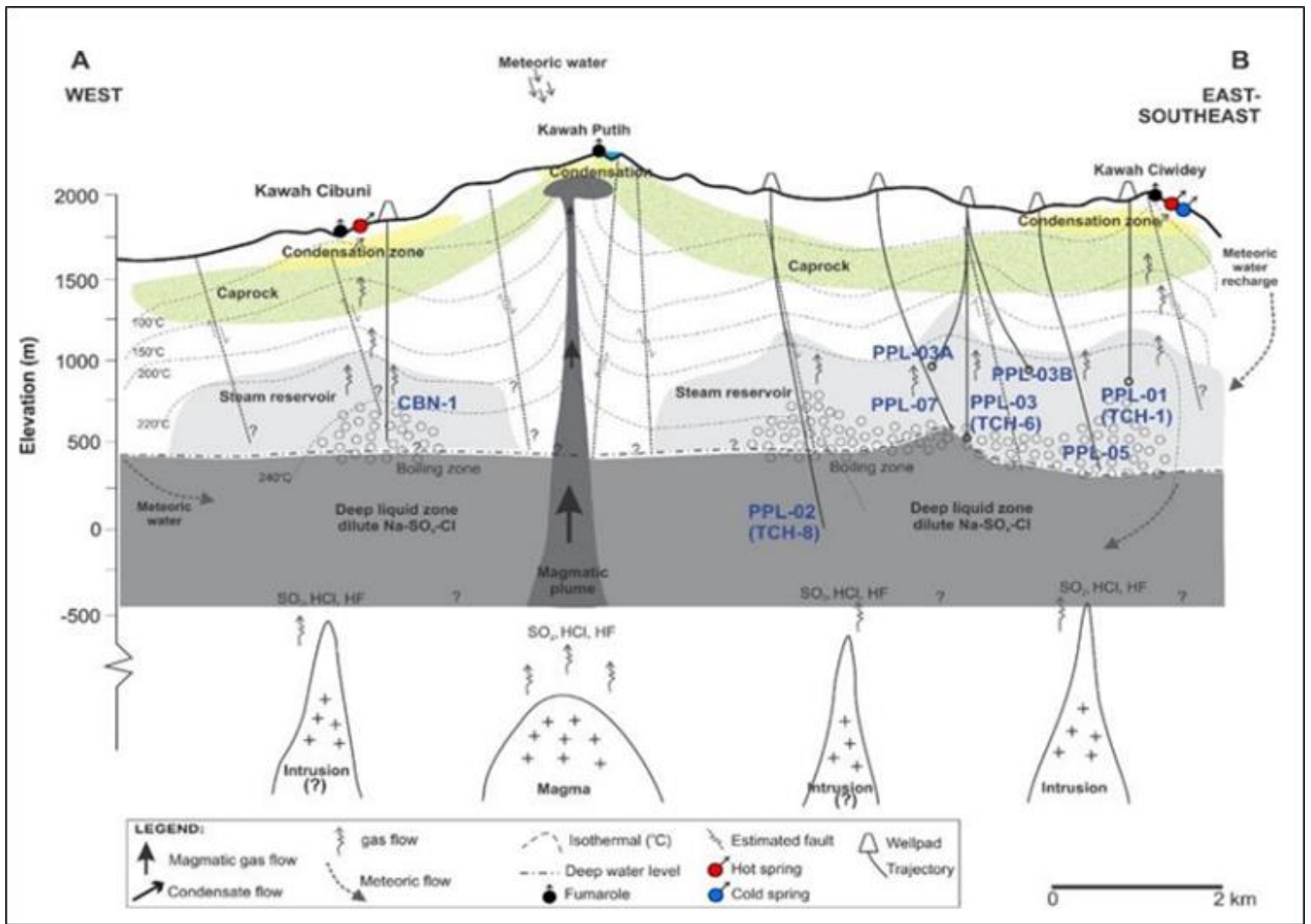

Gambar 7. Model Konseptual Sistem Geothermal di Lapangan Patuha penampang A-B (Ashat, 2017)

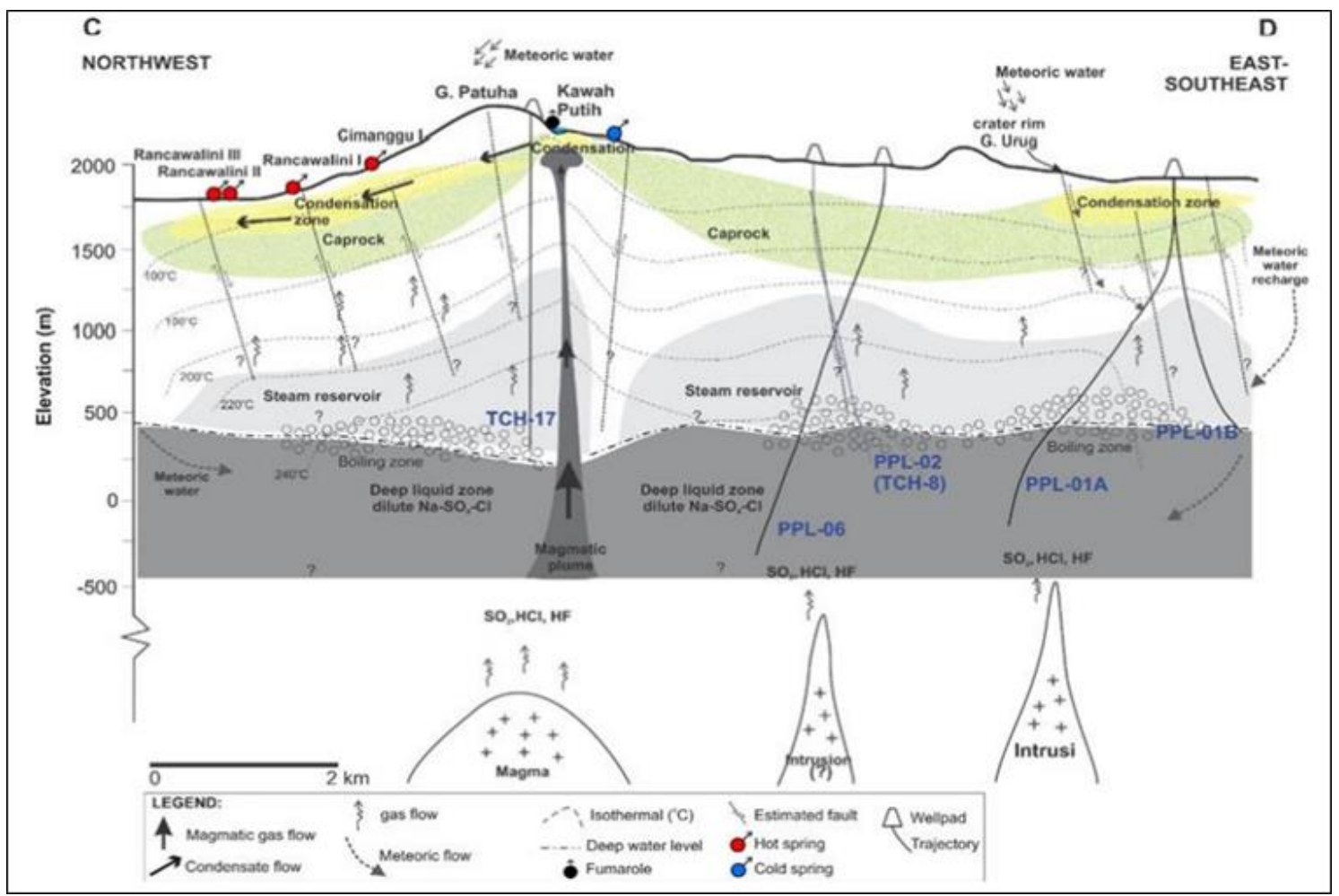

Gambar 8. Model Konseptual Sistem Geothermal di Lapangan Patuha penampang C-D (Ashat, 2017) 
Model konseptual yang dibuat Yosi Amelia (2015) yang disempurnakan oleh Ashat (2017) yang dimuat pada Gambar 7, pada penampang A-B (barat-timur tenggara) memperlihatkan bagian reservoir Kawah Cibuni, Kawah Putih, dan Kawah Ciwidey. Pada penampang C-D yakni model memperlihatkan bagian reservoir Kawah Putih dan reservoir Kawah Ciwidey yang dimuat pada Gambar 8. Keberadaan magmatic plume di area Kawah Putih dan kontrol struktur geologi menyebabkan reservoir dominasi-uap terdapat zona air dan diantarannya terdapat boiling zone area ini terdapat pada PPL-2. Dari Ketiga reservoir tersebut reservoir yang telah dimanfaatkan untuk menyuplai steam untuk PLTP Unit 1 adalah reservoir Kawah Ciwidey. Fluida Kawah Ciwidey berasal dari aliran air meteorik yang masuk ke bawah permukaan, bersirkulasi dan terpanaskan.

\subsection{Pemanfaatan Geothermal Patuha}

Pemanfaatan lapangan panas bumi Patuha dibuktikan dengan dibangunnya PLTP Patuha Unit 1. Pembangkit ini mempunyai kapasitas $1 \times 60 \mathrm{MW}$ yang telah beroperasi sejak tahun 2014 . Pemanfaatan dari WKP Patuha ini menggunakan 7 sumur reservoir aktif hingga saat ini yang dipergunakan untuk menyuplai steam untuk memutar turbin. Kebutuhan uap dengan inlet pressure 11 bar abs, tekanan kondensor 0,1 bar abs, dari hasil perhitungan diperkirakan unit 1 Patuha membutuhkan uap sekitar 370,8 ton/jam atau $103 \mathrm{~kg} / \mathrm{s}$ dengan konsumsi uap rara-rata sebesar 6,75 ton/jamMW.

\subsection{Upaya dan Langkah Strategis Pemanfaatan Energi Panas Bumi}

Dalam upaya pengembangan dan pemanfaatan energi berkelanjutan adalah penguapan uap yang efisien. Langkah yang digunakan dengan melakukan optimalisasi menggunakan pemilihan tekanan inlet turbin dan kondensor. Selain itu dalam upaya meningkatkan kapasitas pembangkit diperlukan pembangunan sumur reservoir baru pada steamfield. Dalam upaya pembangunan dan pengembangan lapangan uap adalah dengan mengoptimalkan lahan kawasan hutan, sehingga lahan hutan yang digunakan tidak banyak. Upaya pelestarian hutan merupakan hal yang sangat mandatory, karena hutan berfungsi sebagai penahan air hujan sehingga tidak menjadi run-off yang akan bermuara ke sungai atau ke tempat lainnya. Air yang tersimpan dibawah permukaan diharapkan masuk ke dalam reservoir sebagai recharge water, sehingga diperlukan upaya untuk melestarikan hutan khususnya di area WKP dan PLTP.

Dalam upaya merencanakan dan memperhitungkan lapangan uap (steam field) antara lain adalah pertama iklim, kedua lokasi pembangkitan dan sumur, ketiga laju produksi uap selama projek berlangsung meliputi karakteristik sumur produksi dan injeksi, seperti tekanan kepala sumur, laju alir massa, temperatur, dan kandungan kimia fluida dari sumur. Selain itu diperlukan perencanaan desain proyek seumur hidup long life sustainability perencanaan seputar keselamatan dan kesehatan kerja serta lingkungan yang memenuhi kriteria operasi dan perawatan, biaya efektif, material yang tepat, dan penyediaan fasilitas pembuangan air dan uap serta memperhitungkan kemungkinan terjadinya scaling. Selain itu diperlukan simulasi reservoir untuk mengkaji beberapa alternatif pengembangan dengan skenario produksi dan injeksi yang berbeda guna memprediksi perubahan yang telah digunakan (Saptaji, 2020).

Skenario produksi dan skenario injeksi merupakan alternatif dalam upaya peningkatan kapasitas PLTP. Upaya yang lainnya adalah dengan mempertimbangkan hasil daripada simulasi reservoir untuk memprediksi perubahan tekanan, temperatur kandungan uap, dan air dalam reservoir 
sebagai dampak eksploitasi sehingga dapat ditentukan kapasitas dan spesifikasi turbin yang akan dipasang di PLTP. Karena desain turbin harus disesuaikan dengan pertimbangan tekanan fluida dari sumur dan kelangsungan produksi uap dalam memuhi kebutuhan pembangkitan.

Perubahan kemampuan sumur produksi sebagai akibar penurunan tekanan dari reservoir harus dipertimbangkan. Hal ini akan berdampak pada produksi dari sumur yang harus diprediksi menggunakan simulasi wellbone simulation. Perhitungan dan pertimbangan dalam prediksi penurunan tekanan pada reservoir perlu dilakukan. Hal ini dapat menyebabkan sumur-sumur dua fasa dominasi air berubah menjadi dominasi uap. Kandungan kimia dalam air dan uap juga akan berubah.

\section{Kesimpulan}

Indonesia merupakan negara yang memiliki potensi panas bumi yang besar dengan cadangan terbukti 29,5 GW. Kapasitas Pembangkit Listrik Panas Bumi yang terpasang di unit Patuha 1 yaitu 55 MW, sedangkan cadangan energi panas bumi terduga adalah $17 \mathrm{MWe}$, cadangan mungkin $210 \mathrm{MWe}$, dan cadangan terbukti adalah 190 MWe. Morfografi dari hasil analisis citra satelit, pola kontur dari peta topografi dan hasil pengamatan lapangan, maka geomorfologi daerah Gunung Patuha dan sekitarnya dapat dibedakan menjadi: Morfologi Perbukitan Gunung api Tua, Morfologi Kerucut dan Kawah Gunung Patuha Muda, Morfologi Kerucut dan Kawah Gunung Patuha Tua, Morfologi Perbukitan Sedang-Landai, Morfologi Dataran Aliran Lahar. Teknologi yang digunakan pada PLTP Patuha Unit 1 adalah siklus uap kering (Direct Dry Steam Cycle) Fluida uap dialirkan secara langsung ke Turbin. Sistem konversi ini merupakan sistem konversi yang paling sederhana. Secara lateral terdapat tiga reservoir di area Patuha yang saling terhubung diantara Kawah Putih Cibuni, dan Ciwidey yang dipisahkan oleh Sesar Normal Cimanggu sehingg memisahkan antara area reservoir Kawah Cibuni dan reservoir Kawah Putih, sedangkan sesar normal Cileulur memisahkan area reservoir Kawah Putih dan area reservoir Kawah Ciwidey. Kebutuhan uap yang digunakan dalam pembangkitan PLTP unit 1 Patuha yakni dengan inlet pressure 11 bar abs, tekanan kondensor 0,1 bar abs, dari hasil perhitungan diperkirakan unit 1 Patuha membutuhkan uap sekitar 370,8 ton/jam atau $103 \mathrm{~kg} / \mathrm{s}$ dengan konsumsi uap rara-rata sebesar 6,75 ton/jamMW. Upaya menjaga dan mengembangkan pemanfaatan energi diperlukan perencanaan desain proyek seumur hidup long life sustainability, dengan mempertimbangkan kondisi lingkungan, prediksi sumur, perencanaan steamfield, dan simulasi reservoir.

\section{Daftar Pustaka}

Amelia Y 2014 Studi Pola Aliran Fluida Sistem Panas Bumi Patuha Thesis Program Magister ITB Press.

Bujung, C. A. N., Singarimbun, A., Muslim, D., Hirnawan, F., \& Sudradjat, A. (2011). Identifikasi prospek panas bumi berdasarkan Fault and Fracture Density ( FFD ): Studi kasus Gunung Patuha , Jawa Barat. Jurnal Lingkungan Dan Bencana Geologi, 2(1), 67-75.

Direktorat Panas Bumi, Ditjen EBTKE, Pusat Sumber Daya Mineral, Batubara dan Panas Bumi, Badan Geologi. (2017). Potensi Panas Bumi Indonesia : Jilid 1. Jakarta : Direktorat Panas Bumi, Dirjen EBTKE, KESDM

Ermawati, T., \& Negara, S. D. (2014). Analisis Kebijakan Pengembangan Energi Panas Bumi di Indonesia. Pengembangan industri energi alternatif: studi kasus energi panas bumi Indonesia. 
Layman E B and Soemarinda S. (2003). The Patuha Vapor-Dominated Resource West Java, Indonesia. Proceedings 28th Workshop on Geothermal Reservoir Engineering (p. SGP-TR173) Stanford: Stanford University.

Pratama H B and Saptadji N M. (2016). Numerical Simulation for Natural State of Two-Phase Liquid Dominated Geothermal Reservoir with Steam Cap Underlying Brine Reservoir. IOP Conf. Series: Earth and Environmental Science 42012006.

Pusat Pengkajian Industri Proses dan Energi (PPIPE). (2020). Outlook Energi Indonesia 2020 Edisi Khusus Dampak Pandemi Covid-19 terhadap Sektor Energi di Indonesia. Jakarta : PPIPE-BPPT

Saptaji, Nenny M. (2012). Teknik Panas Bumi. Bandung : Departeman Teknik Perminyakan, Fakultas Ilmu Kebumian dan Teknologi Mineral, Institut Teknologi Bandung.

Saptaji, Nenny M. (2020). Teknik Geothermal. Bandung : ITB Press

Sekretariat Jendral Dewan Energi Nasional. (2020). Outlook Energi Indonesia 2019. Jakarta: Dewan Energi Nasional

Sekretariat Jendral Dewan Energi Nasional. (2020). Bauran Energi Nasional. Jakarta: Dewan Energi Nasional 